\section{THE BODY AND SEXUALITY IN SIAM: A FIRST EXPLORATION IN EARLY SOURCES}

\section{Barend Jan Terwiel $^{1}$}

\begin{abstract}
In this article some aspects of the relationship between the degree of display of the uncovered body and sexuality are explored, using data from Thai historical sources. A close look at some illustrations in manuscripts from the Ayutthaya and Thonburi periods establishes that prior to the middle of the nineteenth century, Siamese etiquette allowed for large parts of the body to be exposed to public gaze. It is assumed that this may have affected attitudes towards sexuality. A hypothesis whereby the relatively generous display of the human body is correlated with a larger degree of matter-of-factness towards the body and has an effect on courting behaviour is tested on historical and ethnographical data. At first sight the hypothesis appears to be confirmed but because of the scantiness of the data at hand, further research is needed before a proper theory of early Thai sexuality can be developed.
\end{abstract}

\section{Part 1 \\ The body displayed}

In a famous Thai illustrated manuscript, dated $1776^{2}$, there is a dramatic scene from the Temiya Jataka where the young Temiya, sitting on his father the king's lap,

\footnotetext{
${ }^{1}$ Research Fellow at IIAS, Leiden University

${ }^{2}$ From a manuscript held in the Museum of Indian Art in Berlin (Manuscript IC 27507).
}

notes how a group of criminals is being sentenced to death. It is at this moment Temiya decides that he shall avoid the burden of office at all costs.

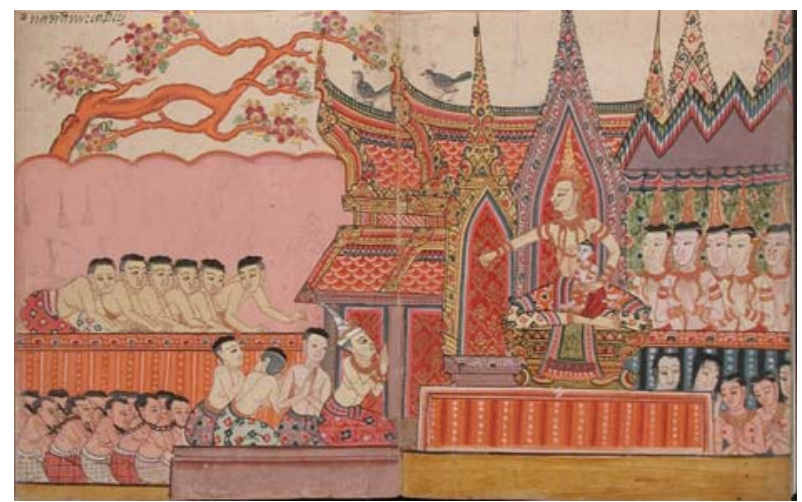

Plate 1

The artist has painted the scene in a contemporary Siamese setting. Between the king and the criminals he has drawn four courtiers, the front one carrying the high headdress, made of white cloth, of a person holding ministerial rank. This minister is shown with his hands respectfully raised in the attitude of hearing and accepting his sovereign's words.

There exists an older picture of the same scene created some time during the Ayutthaya period. ${ }^{3}$

\footnotetext{
${ }^{3}$ From the manuscript Samutphaptraiphum chabap Krung Si Ayutthaya lek thi 6 (Illustrated Three-worlds manuscript, Ayutthaya period, number 6),

Samutphaptraiphum, chabap Krung Si Ayutthaya chabap Krung Thonburi lem 1, khanakammakan fai pramuan ekkasan lae cotmaihet nai khana amnuaikan cat ngan chaloem phrakiat Phrabatsomdet Phracaoyuhua cat phim nueang nai okat phraratchaphithi mahachaloem phrachonma phasa 6 rop, 5 Thanwakhom 2542 (Illustrated Three-worlds Manuscripts, Ayutthaya and
} 


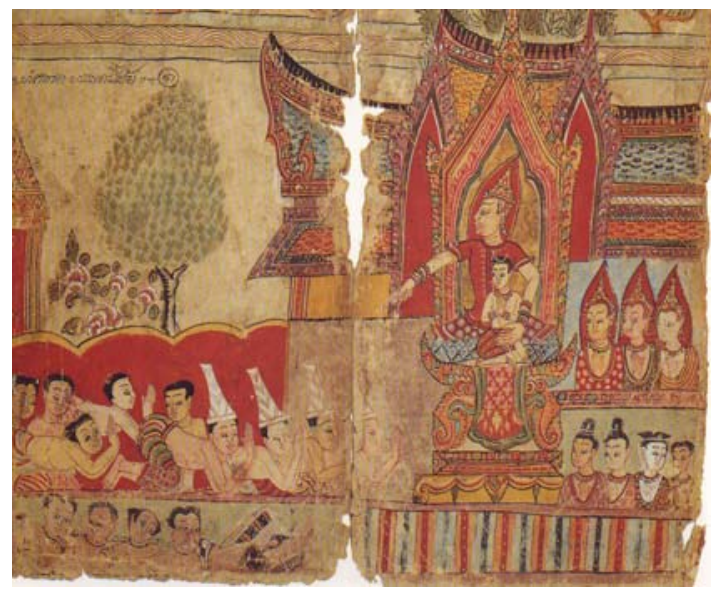

Plate 2

In this older version the king is depicted in an even more confident attitude in the act of pronouncing his decision. It can be noted (as also in Plate 1) that only members of the royal family are adorned with jewels, the king wearing his state crown and, here, Temiya wearing a beautiful necklace. Both father and son are depicted with decorative arm bands.

The people being condemned are joined together by a chain around the necks. In both versions, the courtiers are depicted from left to right in a progressive series: on the left are those of lesser rank, nearest the throne, distinguished by their high ornamental hats are the king's close advisers.

When we closely examine the four chief officials in the older illustration it is clear that they are shown to have distinct physiognomies. It would appear that the

Thonburi periods, Volume 1, Bangkok:

Committee for issuing documents and manuscripts published on the occasion of His Majesty the King's $72^{\text {nd }}$ birthday, 5 December 1999, Plate 83, p. 99. artist wished to indicate people of differing ethnic backgrounds - a feature that fits in with the seventeenth-century Thai court, where Persians, Chinese, and, late in the seventeenth century, a European attained ministerial positions (Dhiravat na Pompejra 1998). The four ministers depicted in this older illustration are all lying down in a much more polite prostrated manner than the single minister in the manuscript of 1776. In the older version the hands are also markedly raised further towards the king at face level, indicating by their posture that they are paying attention to the monarch. However, none of the ministers actually raises his eyes to gaze at the august presence. In contrast, the single minister depicted in 1776 looks straight towards his monarch.

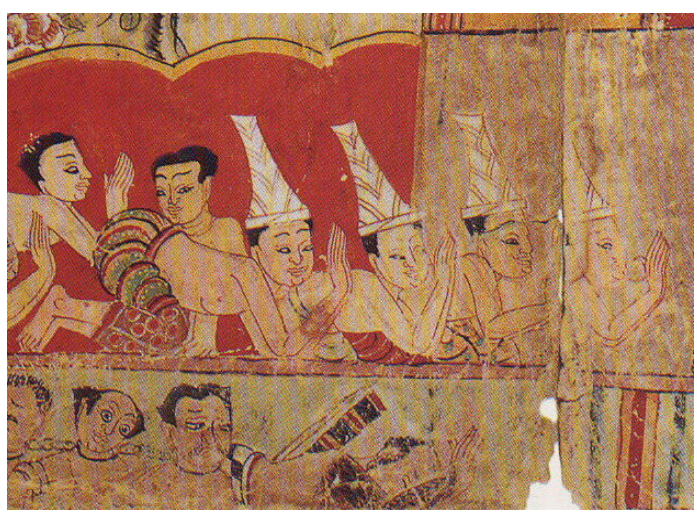

Plate 3

The distinct manner of showing the proper ministerial posture may well reflect a change in court etiquette in the interval between the two drawings of the Temiya Jataka. According to a contemporary Dutch account of the Thai annals (Van Vliet 1975: 83), the practice of letting "the mandarins come creeping before the king and lie constantly with their faces downwards dated from the reign of Naresuan (1590-1605). The artist's drawing of the ministers' posture fits in 
with this description. After the fall of Ayutthaya in 1767, the new court in Thonburi, with Taksin on the throne, may well have been less formal and hierarchical.

All court officials are depicted barefoot and barechested, clothed from the waist to below the knee with tailored garments. In addition, all those attending the audience are free of jewels, rings, necklaces and the like. This lack of ornament is not accidental, it was a standard security measure. All people admitted to an audience would first be required to shed objects that might be magically charged. Such objects, it was generally believed, might allow the wearer to break his oath of allegiance towards the ruler without incurring the terrible consequences mentioned in that oath.

Having established that the artist has depicted the scene in a contemporary setting, I would like to draw attention to the state minister's formal dress code, taking special note of the portions of the body that are covered and those that remain uncovered. There can be no doubt but that the scene shows these high court officials in their best wear, proudly displaying exquisite silken clothes. The bare chest is also a symbol of being in the presence of the highest authority. La Loubère (1986 [1693]: 25) provides us with the general rule: high-ranking men could wear a loose open shirt that had to be taken off, however, when coming into the presence of someone ranking above them. The shirt was described in 1622 as being "of pure white or red or some other colour of cotton cloth with wide, half-long sleeves, open at the front and reaching to the knees..."4

When a European diplomatic mission was received in official audience with the Thai king, such as that of Simon de La Loubère on $2^{\text {nd }}$ November 1687 , the ministers wore shirts of this type, perceived by a French observer as being a kind of whitesilvery cape (Jacq-Hergoualc'h 1992: 95). However, when the European mission was at a lower level, no such ceremony was considered necessary. For example, when Pieter van den Hoorn, chief of the local Dutch trade office formally came to present gifts to the Phra-khlang (the Minister of Trade) in order to negotiate in the name of the East India Company new conditions of trade on $13^{\text {th }}$ March 1690, he and his party had to take off their shoes before entering the reception hall, and when the Minister finally made his formal appearance, he came barebreasted (Terwiel 2003: 111-112).

Women's fashion also involved a generous display of bare skin. The earliest detailed description was written in 1622 by Cornelis van Nijenrode, who tells how women artfully wrapped themselves in cotton cloth that had an embroidered edge, leaving the upper body bare except for a shawl of cotton or fine silk. ${ }^{5}$ What this looked like can be seen in the group of court ladies, depicted in a scene from the Bhuridatta Jataka that dates from the late eighteenth century. ${ }^{6}$ This shows how these

\footnotetext{
${ }^{4}$ From a manuscript kept in the Utrecht Archive, translated by H. ten Brummelhuis, being prepared for publication. I would like to thank him for making the translation available. ${ }^{5}$ From the Utrecht Archive manuscript, translated by $\mathrm{H}$. ten Brummelhuis, mentioned above.

${ }^{6}$ From the manuscript Samutphaptraiphum chabap Krung Thonburi lek thi 10/k
} 
ladies wore beautiful clothes from the waist down whilst the cloth covering the bosom is depicted as an ornamented gauze that allowed the breasts to be seen. According to La Loubère (1986 [1693]: 26 ), only rich women wore such scarves, the poorer classes going without.

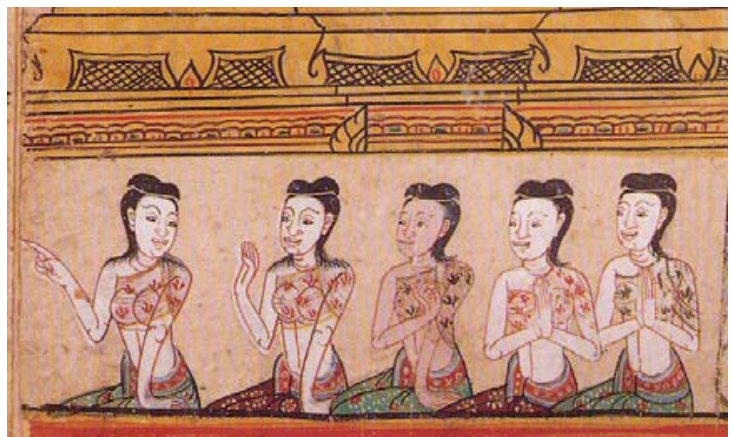

Plate 4

A detail from an illustration of the Kakati Jataka $^{7}$ showing the musician Natakuvera meeting Queen Kakati reveals clearly which parts of the body had to be covered when in public and which not. Males had, at least, to dress themselves with a cloth wrap from the waist to halfway down the thigh and women from the waist to well

(Illustrated Three-worlds manuscript, Thonburi period, number 10/k), Samutphaptraiphum chabap Krung Si Ayutthaya chabap Krung Thonburi lem 2, khanakammakan fai pramuan ekkasan lae cotmaihet nai khana amnuaikan cat ngan chaloem phrakiat Phrabatsomdet Phracaoyuhua cat phim nueang nai okat phraratchaphithi mahachaloem phrachonma phasa 6 rop, 5 Thanwakhom 2542 (Illustrated Three-worlds Manuscripts, Ayutthaya and Thonburi Period, Volume 2, Bangkok: Committee for issuing documents and manuscripts published on the occasion of His Majesty the King's $72^{\text {nd }}$ birthday, 5 December 1999, Plate 141, p. 233.

${ }^{7}$ From the manuscript mentioned in footnote 2, Plate 49, page 65. below the knee. When walking about, the woman's shouldercloth did not need to cover the breasts. The bracelets seen here are indicative of Kakati's high social status.

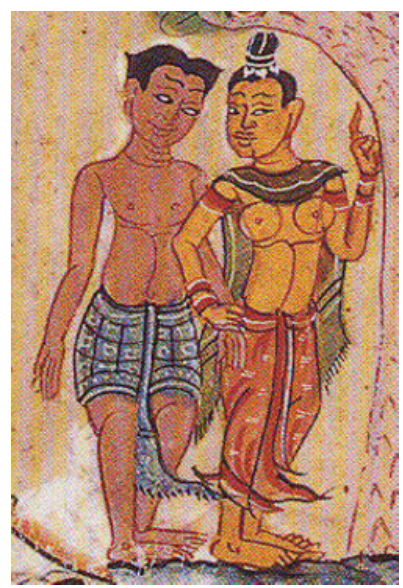

Plate 5

The formal dress code that accepted the bare chest and bare feet was generally observed throughout Siam and can be studied in early murals and illustrated manuscripts as well as in early photographs up to the middle of the nineteenth century. The same amount of bare skin noted in the seventeenth century by Ibrahim in 1685 (O'Kane 1972: 56) or at nearly the same time by Gervaise (1688: 109-110) was commented upon at the beginning of the nineteenth century by Finlayson. The latter remarked (1988 [1826]: 109): "The people generally go naked from the waist upwards, sometimes throwing a piece of cloth over the shoulders. Old women, in general, expose the breast; but the young and the middle aged wrap a short piece of cloth round the chest, of sufficient length to form a single knot in front, thus leaving the shoulders and arms bare." This description by Bishop Bruguière (1831: 151), which was 
written in 1829 , shows that the degree of nakedness had not appreciably changed from the seventeenth century. Since he had a long-standing and intimate knowledge of the Thais his account is not without interest:

The costume of the Siamese is very simple; they go bare-foot and bare-headed and the only covering is a piece of coloured cloth attached at the waist; they fix it at the back, which gives the garment the appearance of trousers (I shall call it a langouti): this is a costume that men and women have in common... ${ }^{8}$

Pallegoix (1969 [1854]: 201-202) repeats this description almost word for word, and adds that women also wore a scarf. When Pallegoix explains the way the scarf was worn, allowing the ends to fall backwards over the shoulder, it matches exactly the way Queen Kakati is depicted in our Plate 5. Men, according to Pallegoix, used a white scarf in a variety of ways: sometimes as a kind of belt, as a cloth to wipe the sweat from their brow; or sometimes as a turban to protect them against the burning sun. When a person prepared himself to meet a superior he had to wrap a silken belt around his waist. The king and the princes differed from their subjects only in the richness of the cloth and the fact that they normally wore Chinese sandals.

Pallegoix (1969 [1854]: 202) also informs us what people wore during the cold season: "From the middle of October until February men and women wear a loose vest. Men and women wear different sorts of vest but wealthy and mighty people also

${ }^{8}$ Translated from the French by the author. like to wear a Japanese top, that looks like a wide, loose blouse, made of Chinese silk in brilliant colours. When it is cold, people may add a silken coat or blanket." These more elaborate clothes of the rich also remained essentially the same, for Gervaise (1688: 110) who describes them in practically the same terms.

Having established the chief dress code in early modern Siam, it does not come as a surprise that one of the earliest posed photographs taken of Somdetchaophraya Borom Maha Phichai Yat (That Bunnak) who lived from 1790 to 1857 , shows him dressed only in a beautiful silken wrap around his waist. ${ }^{9}$

Around the middle of the nineteenth century, when Siam was opened to international trade, the public display of bare skin drastically reduced. At first this took place at court with the reorientation towards the West beginning with the succession of King Mongkut and the preparations for the Bowring treaty in the early 1850s. Hereafter, at least in the Thai capital, European clothing habits were no longer met with derision as was the case in the 1830s (Earl 1837: 165; Ruschenberger 1970 [1838]: 48) but became a convention assiduously studied and emulated. King Chulalongkorn (r. 1868-1910) sent his sons to be educated in England, Germany and Russia, and in two protracted journeys he frequented the most distinguished European circles. He often dressed and liked to be photographed as the consummate European gentleman. The court communicated the new principle that the public display of the chest as well as

\footnotetext{
${ }^{9}$ The photograph has been often reprinted, recently on page 122 of the new edition of the Collected Proclamations of King Mongkut (Charnvit, ed. 2004).
} 
bare feet was tantamount to being at a lower level of civilization. It took some time for the changes to reach ordinary Thais. Adventurous Thais found jobs as scribes with European firms. One of them, the famous Thianwan (1905: 1521), wrote as late as the beginning of the twentieth century: "I cut my hair, wore a moustache, no longer chewed betelnut and dressed myself in the new way and wore shoes and socks earlier than all others in Siam".

The decision to accept European standards of civilisation and the concomitant adaptation of Siamese rules of dressing up began in the court, spread to the capital and slowly made its influence felt in the provinces. During the period of heightened nationalism in the 1930s and early 1940s, still inspired and guided by European ideas of civilisation, the government took great pains to educate Thais in being "properly" dressed. High-ranking government committees made lists of what was proper and what ought to be avoided. School uniforms, complete with socks, shoes and shirts, became the norm. In municipal areas it became forbidden to appear in public with a bare chest and this rule also included workers on construction sites. Much of that strong campaign eventually became accepted and led to the present-day dress code that is generally kept at all public gatherings whereby as little skin is left to the observer's gaze as in European countries.

Only in some faraway rural regions were the ancient clothing rules still observed, notably in places where the electricity grid had not yet been established, where roads and bridges did not yet allow easy access. During the 1960s the author of this contribution had the privilege of spending a prolonged period doing fieldwork in one such village. Everyone walked barefoot and, consequently, next to every access to a human habitation there stood a large earthenware pot containing water, together with a ladle made from half a coconut shell on a long wooden handle. Before entering the house one poured water over one's feet firmly rubbing them together, on muddy days an action needing considerable skill. On hot days the old lady who allowed me to stay in her house merely covered her chest with loose cloth, not unlike in the pictures on the old murals. On festive days, however, even in that poverty-stricken village, everyone dressed up like town people, the men wearing trousers and shirts and all the women covered with wraps and blouses.

\section{Part 2}

\section{The body and sexuality}

It is well-known in European history of the seventeenth, eighteenth and nineteenth centuries how, especially in the higher echelons of society, the rituals of courtship involved elaborate preparations by members of both sexes whereby the body was almost totally covered. According to contemporary fashion, both men and women partially transformed their appearance with various contraptions hidden in and under layers of cloth. On formal occasions both males and females had to dress up in impressive outfits, thereby supporting countless manufacturers of corsets, hairdressers, dressmakers, tailors, haberdashers, hat-, shoe- and stocking makers, as well as suppliers of make-up, perfumes and ribbons. According to the ideal, a couple would meet, be attracted to each other and proceed through a courtship without seeing much of the other's body and having to guess what the future partner actually looked like when undressed. This by itself may well have been conducive to 
stimulating the imagination and must have become a strong element in European sexuality of that time.

The description of the traditional Siamese dress code described in the first part of this article may be taken as an indication that Thais must have had a considerably different experience of courtship. Their language of sexual signals was less determined by the elaborate covering-up of the figure. Thai men could not resort to increasing their attractiveness by cunningly broadening their shoulders and women did not learn how to create an alluring corsage. The art of making-up the face appeared to have limited itself for Thais to a very simple and rather quick application of white powder. La Loubère noted the same: "The Women use neither Paint nor Patches.." (1986 [1693]: 27). This is not to say that Thai courting lacked excitement. It is suggested here that, partly because of the large expanse of bare skin visible, Siamese courting developed in a quite different direction from its European counterpart. A courting Thai couple, under chaperon, would be acutely aware of the visual and olfactory impact of each other. Rapture might also result from a certain way of eye contact, from subtle signs through the inclination of the head, through comportment and many other elements of body language. Courting was often accompanied by elaborate playful verbal exchanges and not only the poetical contests in court circles that we may deduce from some of the works of Sunthorn Phu but also in rural settings (Wijeyewardene 1968). ${ }^{10}$

In contrast to people brought up in puritan Europe, the Siamese at that time had a clear idea of what the bodies of members

${ }^{10}$ Compare also Compton 1979. of the other sex looked like. Moreover, a glimpse of a woman's breasts or a patch of bare stomach, so laden with sexual meaning in Europe, may have caused much less excitement in Siam. Naturally, when courting, the sight of the beauty of the bosom of one's intended brought to the fore its sexual role and in an early legal code, pinching a woman's bare breast against her will was specifically mentioned as an offence (Aroonrut and Wijeyewardene 1986: 22, 88).

While in both Europe and Siam a woman who was marrying for the first time should, ideally, be a virgin, there was a marked difference in the degree of prudery. Many a bride and groom in Europe - often only vaguely aware of the physical act leading to procreation possibly dreaded the ordeal of their first wedding night. Thais in general seem to have been more matter-of-fact and the traditional instructions given to the bride and groom concentrated on practical rules of wisdom and teaching them how to get along.

Having postulated a relatively larger measure of realism regarding matters concerning human sexuality among Thais, this may not be confused with crudity. Thais generally have always tended to avoid the public display of the genital region; public nude bathing, for example, or walking naked through a public space towards a shower is generally felt to be deviant behaviour. This phenomenon can be observed today but it was also the case in the late seventeenth century (La Loubère 1986 [1693]: 26-27). A French diplomat remarked that (in contrast to Europe) Thai children were not chastised by a beating on the bare buttocks. He assumed that the Thai use of a cudgel (instead of a whip or a rod) to chastise was 
related to the fact that only such a heavy object would be felt through their clothing.

With respect to the attitude towards their genitals Thais draw a marked distinction between the sexes, however. This is apparent when noting the difference in the covering of male and female babies. When they are very warm, male babies are often left naked, regardless of whether strangers are around to see them. Baby girls on the other hand wear a tiny loose covering, often a triangular bit of metal mesh hung from a rope bound around the waist, in front over the genital region (the so-called "cha'ping"). Small boys in poor surroundings or isolated villages may walk around naked till they have almost reached school age while small girls must at least wear shorts. The reason why girls are treated differently lies in the fact that it is considered indecent to have the vagina exposed, the reason being usually given in words meaning something like "it is not something you want people to look at".

Traditionally, in Thailand people had a limited notion of privacy; at any time people of all ranks could assume that someone might be in a position to observe or hear them. Dressing and undressing usually took place in locations where other people were present and even when alone people tended to behave as if in public. The changing of the loincloth always took place under a covering wrap. This can be observed not only in modern rural Thailand but it was also reported in seventeenth-century Siam. This was then, as now, simply a matter of good manners; Thais were and still are scrupulous in avoiding exposure those "parts of their body, which custom obliges them to conceal" (La Loubère 1986 [1693]: 26).
At the same time, this avoidance of display ought not to be confused with an excessive measure of prudery. Everybody was quite aware of what the penis looked like. If, for example, a fairly senile old monk were to sit in such a way that his robe allowed passers-by to see his genitals, not much fuss would be made: a gentle hint or an assisting hand readjusting his clothing would be regarded as a proper reaction. Neither was there a marked avoidance of watching or handling effigies of the erect penis. A wooden phallus (Thai: ai khik) could be worn by males on a cord around the waist as a protective amulet. In shops where amulets were traded dozens of these erect penises could be prominently displayed without causing offence. Not only in amulets but also in tattooing an ejaculating erect penis could function as a powerful protective symbol and be tattooed on the lower part of the body. In certain rain-making ceremonies huge wooden penises were carried about.

The attitude towards the vagina was quite different. Even symbolically female genitals were hardly ever on display. This is in marked contrast to the Indian tradition and it may be related to the fact that for Thais menstrual blood is regarded as one of the most powerful and dangerous magical substances, reputedly used by women as the most powerful ingredient in love potions, a substance designed to bind the object of their desires, counteracting all male magical protective devices. Men were therefore warned to avoid sexual intercourse when the woman was having her period (Kaufman 1977: 148). In addition, it was common knowledge among men that if they allowed a woman to sit on top of them during sexual intercourse, they would lose the protective magical powers of all their tattoos. 
The ethnographic accounts describing the assiduous chaperoning of courting couples are in marked contrast to older travel accounts, particularly those of the sixteenth and seventeenth century, which abound with tales of the loose sexual mores of Southeast Asian women. ${ }^{11}$ This apparent contradition may well have beeen caused by a hitherto overlooked strong bias in the early sources. To a sixteenth- or seventeenth-century European visitor, accustomed to a much more elaborate way of dressing in public, the Siamese very way of walking around in public, described above, with large portions of the body uncovered, in particular the casualness with which a woman's breasts were exposed, may well have been falsely interpreted as a clear sign of laviciousness.

Those early European accounts of Siamese permissiveness should be read and interpreted with some caution. In the first place, stories of Siamese women being unusually willing to enjoy casual intercourse with strangers fit in well with the stories of wondrous exotic oriental countries that became popular in European circles. Secondly, in all places where rich merchants established a trading office the sexual needs of these traders offered an unusual incentive for the indigenous women to enter upon an adventurous career, even though by entering into regular contact with Europeans and by providing them with sexual favours they were bound to become marginalised in their own society. The most explicit account of this situation was given by the surgeon, Gijsbert Heeck, in 1656. Writing about the Dutch traders living in a compound not far outside the capital city he comments:

${ }^{11}$ For an overview, see Trakulhun 2006: 166189. ...they live very luxuriously here, most of them keeping concubines or kept women, in order (as they say) to avoid common whores. They pay them maintenance for all their needs, buy or build them a house, each according to his capacity. They say that this may just be permissible because it is legal (in the manner of the Siamese) and, also, they do not possess the virtue of abstinence and, furthermore, are completely deprived of Dutch wives (their equals). They add to this Paulus' aphorism that it is better to marry in such a way than (having lived with whores) in the next life to burn. But how wrong it is shown sufficiently in the words and deeds themselves, because, they themselves, including the director (because almost nobody is free of this vexation), address them seldom better than as whore, trollop, slut and the like. He who just earns enough to keep such a sow-like woman has to have his own 'jewel', even if he will have not a penny left on his account. Indeed I myself have noticed that several stand deeply in debt. As for the children, as long as the fathers remain here things are reasonably in order but for most of the time they keep them in their rooms, most of them having one or two of them, so that they have no cause to reproach one another but when they leave, the women claim a large sum of money in advance from the Company on their account. They can live on this money but spend it mostly all at a certain Tomas the Frenchman. This man is a free burgher who 
lives not far from the lodge. $\mathrm{He}$ makes his living by tapping beer, arak and punch for the sailors and others in this area. He originally came on a ship from Batavia and was accidentally stranded here and, having his freedom, he made his residence here. Our people usually call his establishment 'the orphanage'. The fate of these poor orphan children can be easily imagined. ${ }^{12}$

Short-term European visitors, such as sailors, would have their sexual needs catered for in establishments such as the "orphanage" mentioned by Heeck. Europeans had little or no opportunity to travel outside their assigned quarters and none appeared to have been in a position to judge the degree of sexual liberty of ordinary Thai men and women in general. Similarly, Ma Huan's much-cited passage describing how Chinese men could freely sleep with Siamese women, their husbands taking no exception to it (Ma Huan 1997: 104) would seem to be similarly flawed. It appears rather to refer to experiences in a brothel, or some such similar situation, and should not be taken as a comment on Thai women in general.

If the traditional literary genre of didactic poetry may be taken as containing a guide to normative traditional attitudes towards sex, the average young woman is by no means free to engage in sexual relationships before marriage and, whilst divorce may be relatively easily organised when a marriage is proven to have failed,

${ }^{12}$ Translated from the Dutch manuscript in the National Archive in The Hague (01.11.01.01, inv. Nr. 959) fol. 77. taking a lover whilst still being married is definitely discouraged. ${ }^{13}$

While didactic poetry may reflect more the norms of the upper classes, the few anthropological studies of village life in central Thailand also point to a strong social pressure towards controlling women's sexuality. Marriageable women tended to be chaperoned when meeting members of the opposite sex. It was not easy for lovers to find an unobserved spot to meet. Usually they had to hide in the cover of darkness near a rice field to explore their sexuality. A woman who became pregnant before marriage was severely punished within the community by being scolded and made to feel ashamed. ${ }^{14}$ By having sex before marriage, she prevented proper marriage arrangements, making a farce of the customary process of negotiating a bride price.

After marriage sexual intercourse took place in the dark, keeping as silent as possible so as not to disturb other people sleeping in the house (see also deYoung 1955: 48). This secrecy may well have heightened excitement among married couples but it most probably prevented those couples from more than a cursory exploration of each other's body and from developing a regular and, in the long run, satisfying sexual relationship. This perspective adds a little-discussed perspective to the role of brothels in Thailand.

\footnotetext{
${ }^{13}$ See for example the Suphasit son Ying, written early in the nineteenth century. A translation in the German language can be found in Wenk (1985: 309-346). See also Aroonrut and Wijeyewardene (1986: 22, 88).

${ }^{14}$ This has also been observed among the Phuan in Thailand and Laos (Snit Smuckarn and Kennon Breazeale 1988: 157).
} 
The relatively relaxed attitude towards sexuality in old Siam may also be tested by looking at homosexuality. Accounts of homosexual relationships are difficult to find in Thai historical sources, the topic seldom cropping up in the wide range of traditional literary genres. Moreover, when a mention is made, it is impossible to determine what exactly is meant, for there is quite a range of erotic behaviour that warrants this label, ranging from fleeting homosexual fantasies and episodic experiences to obligative attitudes. The few snippets of information that can be gathered point to a very relaxed attitude towards people with homosexual preferences, an attitude remarked upon by some contemporary researchers. Much attention has been given to effeminate homosexual males of Thailand known as kathoei, who often can be seen playing quite humorous roles in Thai television serials.

The only case of male homosexuality in Ayutthaya that has come to light during the early seventeenth century is the case of Joost Schouten and this only because he continued his preferred sexuality after having left Siam. Schouten had been an assistant and later a sub-merchant in the Dutch lodge at Ayutthaya between 1624 and 1629. In 1629, the lodge was temporarily abandoned but when it was reopened in 1633 Schouten, now with the rank of chief merchant, was appointed director, until he was replaced in 1636 by Jeremias van Vliet. Schouten continued serving the VOC in various missions rising to the position of Councillor of State in Batavia. In July 1644, however, he was accused, tried and convicted for the heinous crime of "sodomy", read "homosexual relations". In the puritanical environment of Batavia, where the Dutch Reformed Church played a prominent role,
Schouten's admission to sexually deviant behaviour constituted a scandal of the first rank.

Notwithstanding Schouten's good professional track record and various people pleading leniency by referring to his extraordinary services to the VOC he was publicly executed.

Before his death, he made a full confession, admitting his guilt. $\mathrm{He}$ revealed having begun this vice in Siam. In his biographical essay on Schouten C.R. Boxer notes the striking contrast between the Dutch abhorrence of such acts and the leniency in East Asian cultures, notably in Japan, where (citing Francois Caron) "it is no sin nor shameful thing" Boxer, 1935: 142-143.

One of the eyewitnesses to this execution was the same Dutch physician Gijsbert Heeck mentioned above. A decade after the event he remembered Schouten's nefarious deeds as follows:

[The Lodge at Ayutthaya] was founded in the year 1634 by Joost Schouten, who was then the director here but who later, in 1644, was strangled and burned to ashes in my presence in Batavia because of his gruesome sodomy. He was a man of unusual knowledge and extraordinary intellect, having been elevated through his ability and capacity to Member Ordinarius of the Council of India but in his heart he was a hypocritical villain and seducer of many, secretly using his prominence and great authority to force them away from the path of decency into the way of his shameful foulness, seeking 
thereby to satisfy his devilish lechery, [the gratification of] which is in every respect impossible (it being Satan's work). Therefore, those who were known [i.e., to have taken part in his evil deeds] were, either with him or later, in a (similarly untimely) way, smothered under water since they were unworthy to continue living among humans which is a fitting recompense and retribution for their gruesome life on earth. In the hereafter, however, the worst is still to come. But it is not for us to judge. $^{15}$

Schouten's homosexual acts during his long stay in Siam would not have been noted if he had not mentioned them himself. Indeed, such behaviour (if known) might have been considered eccentric, rather than scandalous in traditional Siam, if the following account may be taken as guide.

The only casual direct reference to a Thai of high rank having sex with males can be found in the account of the court case against Prince Rakronnaret. In 1848 this prince was accused of having abused his position as judge. During the subsequent enquiry Rakronnaret's personal life style was scrutinised and it was remarked how he liked to frequent actors and let himself be sexually satisfied by these actors' manual manipulation. The prince reacted by stating that such matters had no bearing on the accusation and that what he did with his sexuality in private was nobody's

\footnotetext{
${ }^{15}$ Translated from the above mentioned Dutch manuscript in the National Archive in The Hague (01.11.01.01, inv. Nr. 959) fol. 75.
}

business (Thiphakorawong 2504 B.E.: 132-136). ${ }^{16}$

\section{Conclusion}

In this contribution at first the formal dress code in traditional Thailand was examined by referring to some illustrated manuscripts. It was established that in central Thailand, even during an audience with the king, the feet and the upper part of the body were left bare. This etiquette was generally followed until the middle of the nineteenth century. Before the middle of the twentieth century new formal clothing rules were put in place and were followed in the whole of the country.

In the second part of this article the hypothesis that the common display of large parts of the body affected the Thai attitude towards the body in general and sexuality in particular was tested. Compared with contemporary European mores, the Thais appeared to be much more matter-of-fact in matters sexual. However, this did not result in a large degree of sexual freedom. Throughout the period of study Thais remained extremely reluctant to expose the genital region but a difference between men and women was noted. Early Chinese and European accounts on the very lax Siamese sexual habits, it was asserted, should be read with caution, for they may well reflect personal experiences only and need not have any relation to the general rules of morality at the time. Indeed, the information from traditional literature as well as from early anthropological studies points to a strong

\footnotetext{
${ }^{16}$ Later during the investigations it became clear that Rakronnaret indeed had abused his high position and that he held seditious opinions. He and three of his associates were put to death.
} 
wish to control young women's sexuality prior to marriage.

\section{References}

Aroonrut Wichienkeeo and Gehan Wijeyewardene (transls and eds). 1986. The Laws of King Mangrai (Mangrayathammasart), Canberra: The Australian National University.

Boxer, C. R. 1935. A True Description of the Mighty Kingdoms of Japan \& Siam by François Caron \& Joost Schouten, London: The Argonaut Press.

Bruguière, Bartholomeu. 1831."Lettre de Mgr Bruguière, évêque de Capse, à $\mathrm{M}$. Bousquet, vicaire-général d'Aire" Annales de l'Association de la Propagation de la Foi, 5, 63-215.

Charnvit Kasetsiri (ed.). 2004. Prachumprakat Ratchakan thi 4, Bangkok: Toyota Thailand Foundation.

Compton, Carol J. 1979. Courting Poetry in Laos: A Textual and Linguistic Analysis, Northern Illinois University, Center for Southeast Asian Studies, Special Report No. 18.

deYoung, John E. 1955. Village Life in Modern Thailand, Berkeley and Los Angeles: University of California Press.

Dhiravat na Pompejra. 1998. "Port, Palace, and Profit: An Overview of Siamese Crown Trade and the European Presence in Siam in the Seventeenth Century"Port Cities and Trade in Western Southeast Asia, Bangkok: Chulalongkorn University, Institute of Asian Studies, 65-83.
Earl, G. W. 1837. The Eastern Seas, or Voyages and Adventures in the Indian Archipelago, in 1832-33-34, London: Allen.

Finlayson, George. 1988 [1826]. The Mission to Siam and Hué 1821-1822, Oxford in Asia Hardback Reprints, Singapore: Oxford University Press.

Gervaise, Nicolas. 1688. Histoire naturelle et politique du royaume de Siam, Paris: Claude Barbin.

Jacq-Hergoualc'h, Michel. 1992. Journal du voyage de Siam de Claude Céberet, Envoyé extraordinaire du Roi en 1687 et 1688, Paris: L'Harmattan.

Kaufman, Howard Keva. 1977. Bangkhuad: A Community Study in Thailand, Rutland: Tuttle.

La Loubère, Simon de. 1986 [1693]. The Kingdom of Siam, Singapore: Oxford University Press reprint.

Ma Huan. 1997. Ying-yai Sheng-lan, The Overall Survey of the Ocean's Shores (translated by J. V. G. Mills), Bangkok: White Lotus reprint.

O'Kane, John (transl.). 1972. The Ship of Sulaiman, Persian Heritage Series No. 11. London: Routledge \& Kegasn Paul.

Pallegoix, Jean Baptiste. 1969 [1854]. Description du royaume Thai ou Siam, Vol. 1, Farnborough: Gregg International Reprint.

Ruschenberger, W. S. W. 1970 [1838]. Narrative of a Voyage Round the World,During the Years 1835, 36, and 37, Part 2, Reprint, Folkestone: Dawsons. 
Snit Smuckarn and Kennon Breazeale.

1988. A Culture in Search of Survival:

The Phuan of Thailand and Laos, Monograph Series 31, Yale University

Southeast Asia Studies, New

Haven:Yale University.

Terwiel, Barend Jan (ed.) 2003. Engelbert Kaempfer in Siam, Engelbert Kaempfer Werke, Vol. 4, Munich: Iudicium.

Thianwan. 1905.

Tunlawiphakphotchanakit, Vol. 4.

Thiphakorawong, Chaophraya. 2504 B.E. (1961). Phraratchaphongsawadan

Krung Rattanakosin Ratchakan thi 3, Vol. 2, Bangkok: Khurusapha.

Trakulhun, Sven. 2006. Siam und Europa; Das Königreich Ayutthaya in westlichen Berichten, 1500-1670, Hannover: Wehrhahn Verlag.

Van Vliet, Jeremias. 1975. The Short History of the Kings of Siam, translated by Leonard Andaya, Bangkok: The Siam Society.

Wenk, Klaus. 1985. Texte und Interpretationen von und zu Sunthon Phu und seinem Kreis, Studien zur Literatur der Thai, Volume 2, Bangkok: Duang Kamol.

Wijeyewardene, Gehan. 1968. The Language of Courtship in Chiangmai, Journal of the Siam Society, 56, 1: 32. 